\title{
Radial Artery Pseudoaneurysm as a Rare Complication after Transradial Coronary Angiography
}

\author{
Transradiyal Koroner Anjiyografi Sonrası Nadir Bir \\ Komplikasyon Olarak Radiyal Arter Psödoanevrizması
}

\begin{abstract}
Compared to transfemoral coronary angiography (CAG), transradial CAG has been associated with less access site complications, shorter hospitalization, better patient comfort, and early mobilization. However, the use of radial access in CAG may also cause entry site complications. Radial pseudoaneurysm after transradial CAG is a rare complication reported in less than $0.1 \%$ of the procedures. In this report, we present a 78-year-old patient who was diagnosed with right radial artery pseudoaneurysm by Doppler ultrasonography after transradial CAG and treated nonsurgically.
\end{abstract}

Keywords: radial artery pseudoaneurysm; radial artery ultrasonography; transradial coronary angiography

\section{Öz}

Transradiyal koroner anjiyografi (KAG), transfemoral KAG'ye kıyasla daha az girișim yeri komplikasyonu, daha kısa hospitalizasyon, daha iyi hasta konforu ve erken mobilizasyon ile ilișkilendirilmektedir. Bununla birlikte, KAG'de radiyal girișim kullanımı giriş yeri komplikasyonIarına da neden olabilir. Transradiyal KAG sonrası radiyal arter psödoanevrizması, ișlemlerin \%0,1'inden azında bildirilen nadir bir komplikasyondur. Bu raporda transradiyal KAG sonrası Doppler ultrasonografisi ile sağ radiyal arter psödoanevrizması tanısı konan ve cerrahi dıșı yollarla tedavi edilen 78 yașında bir hasta sunulmuștur.

Anahtar Sözcükler: radiyal arter psödoanevrizması; radiyal arter ultrasonografisi; transradiyal koroner anjiyografi
Mehmet Kis', Elton Soydan²

1 Department of Cardiology, Silopi State Hospital

2 Department of Cardiology, Ege University Faculty of Medicine

Received/Gelis : 17.04.2010 Accepted/Kabul: 02.06.2020

DOI: 10.21673/anadoluklin722102

Corresponding author/Yazışma yazarı Mehmet Kış

Nuh Mah., 642 Sk., Bilin Apt., daire no 8, Silopi, Șrnak, Turkey

E-mail:drmehmet.kis@hotmail.com

ORCID

Mehmet Kis: 0000-0003-0775-8992 Elton Soydan: 0000-0002-9897-5484 


\section{INTRODUCTION}

Femoral access is the most preferred method for catheterization and cardiac intervention. However, compared to traditional femoral artery interventions, the use of radial access has lately become more popular for reducing the access site complications $(1,2)$. Compared to transfemoral coronary angiography (CAG), transradial CAG has been associated with less access site complications, shorter hospital stays, better patient comfort, and early mobilization (3). However, the use of radial access in CAG may also cause entry site complications, most notably symptomatic radial artery occlusion, nonocclusive radial artery injury, and radial artery spasm (4). Radial artery pseudoaneurysm, which usually occurs secondary to traumas or invasive procedures such as arterial catheterization, is a rare complication caused by the deterioration of the arterial wall structure. Radial pseudoaneurysm after transradial CAG is reported in less than $0.1 \%$ of the procedures $(1,4)$. Although it can be detected immediately, in most cases it remains asymptomatic for months, leading to delayed diagnosis. The diagnosis is usually made by physical examination, Doppler ultrasonography (USG), or angiography. In this report, we present a patient who was diagnosed with right radial artery pseudoaneurysm by Doppler USG after transradial CAG and treated nonsurgically.

\section{CASE}

The 78-year-old female patient had a history of hypertension and coronary artery disease. Transradial CAG was performed with a diagnosis of chronic ischemic heart disease due to chest pain and ST-T segment wave changes on electrocardiography (ECG). On physical examination, the patient was conscious, well-oriented, and able to cooperate. Pulmonary examination showed that both hemithoraxes participated in respiration equally, with no rales or rhonchi. Cardiovascular examination revealed $\mathrm{S} 1+$, $\mathrm{S} 2+$, rhythmic heart sounds, and 3/6 systolic murmur at the aortic area. Echocardiography revealed a left ventricular ejection fraction of $52 \%$, normal right ventricular ejection fraction, 1-2 degree tricuspid regurgitation, 2 degree aortic regurgitation, left ventricular diastolic dysfunction, and left ventricular hypertrophy. As the patient was scheduled for transradial CAG, radial Doppler USG was performed to evaluate the radial artery patency and diameters before the procedure, with the GE Healthcare Vivid E9 4D cardiovascular ultrasound system device, $11 \mathrm{~L}-\mathrm{D}, 4.5-12 \mathrm{MHz}$ probe. The radial artery was open and radial artery flow rates were normal. Radial artery access was performed after $2 \mathrm{ml}$ of prilocaine was injected into the region. The right radial artery access was achieved with a 21 -gauge open needle. Successful puncture was followed by the insertion of the 0.018-inch straight-shaped guidewire. The needle was removed and a radial hydrophilic sheath (6 French Prelude 170 Ease, Merit Medical) was introduced into the right radial artery. 2500 units of unfractionated heparin, $200 \mathrm{mcg}$ of nitrate and saline cocktail were administered to prevent radial spasm. Right 3.5 size $6 \mathrm{~F}(2.1 \mathrm{~mm})$ and left 3.5 size $6 \mathrm{~F}(2.1 \mathrm{~mm})$ diagnostic catheters and right 3.5 size $6 \mathrm{~F}(2.0 \mathrm{~mm})$ and left 3.5 size $6 \mathrm{~F}(2.0 \mathrm{~mm})$ guiding catheters were used in the $\mathrm{CAG}$ procedure. The guidewire used for the advancement of the catheters was 0.035 inch, $180 \mathrm{~cm}$ in size. Coronary angiography revealed normal left main coronary artery and severe right coronary artery stenosis. 5000 units of heparin were used during the operation. A bare metal stent was implanted into the RCA stenosis. Early mobilization was achieved at the end of the procedure. Radial sheath was removed and early hemostasis was achieved by manual compression for 20 minutes. A pressure bandage was applied after the manual compression, and removed after 4 hours. In the physical examination at the $24^{\text {th }}$ postoperative hour, the patient did not have any complaint and pulsatile, palpable thrill and auscultation murmur were observed in the radial artery region. Based on this finding, radial Doppler USG was performed and a pseudoaneurysm of $0.51 \times 0.35 \mathrm{~cm}$ in size was detected. For a total of $45 \mathrm{~min}$, compression was applied to the region with linear echo probe at 10 minute intervals with the assistance of radial Doppler USG. After 3 days and at 1-week intervals recompression was applied. One month later, radial Doppler USG showed that the pseudoaneurysm disappeared. The patient had no pain when the normal range of movement was attempted and she was able to perform her daily activities. Also, there was no impairment in hand functions.

\section{Report ethics}

Written informed consent was obtained from the patient for the publication of this report and the accompanying images. 


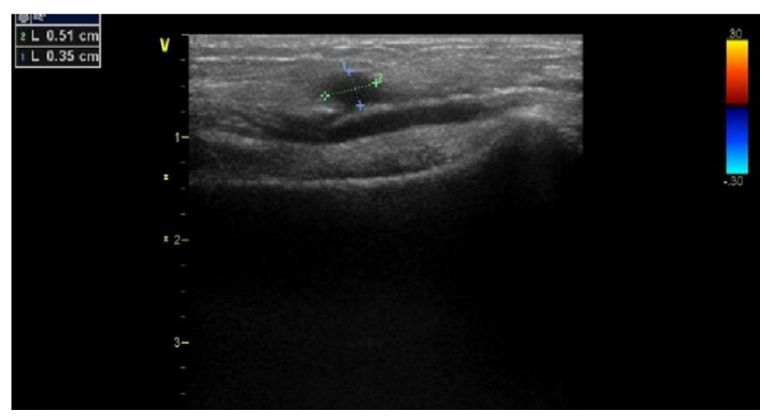

Figure 1. Radial artery pseudoaneurysm $(0.51 \mathrm{~cm} \times 0.35 \mathrm{~cm})$ on the postprocedural $24^{\text {th }}$-hour radial Doppler USG

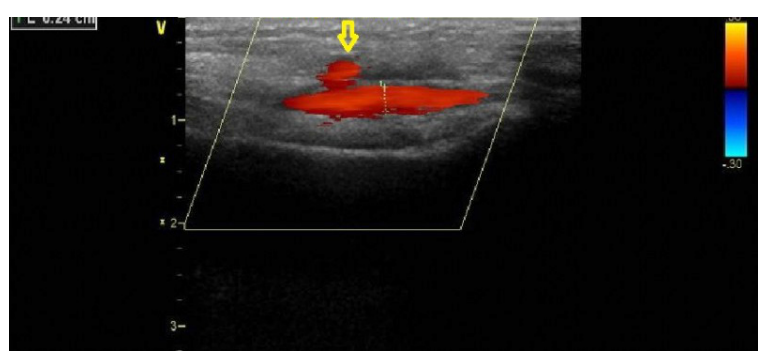

Figure 2. The $24^{\text {th }}$-hour radial Doppler USG showing the flow between the radial artery and pseudoaneurysm

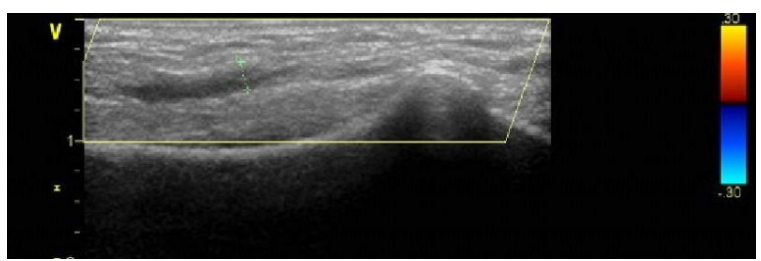

Figure 3. The first-month follow-up USG showing that the pseudoaneurysm disappeared after compression treatment with linear ultrasound probe

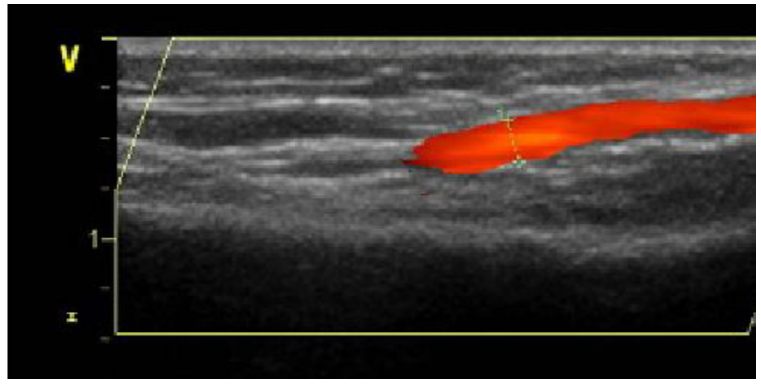

Figure 4. The first-month follow-up radial artery Doppler USG showing that the flow between the pseudoaneurysm and radial artery was cut off after the treatments

\section{DISCUSSION}

Pseudoaneurysm formation after transradial CAG is very rare (occurring in approximately $0.05 \%$ of the procedures), and the radial artery is the most atypical arterial area for pseudoaneurysm formation (5). Only 4 (0.02\%) cases of radial artery pseudoaneurysm were detected during the 17204 procedures performed in a center between 2003 and 2015 (6). The complication has been associated with repeated arterial puncture attempts and catheter infections. Other predisposing factors include old age, longer catheterization time, large sheath diameter, anticoagulant or antiplatelet drug use, and coagulation disorders $(5,7)$. In patients on long-term anticoagulant therapy, the risk of radial artery occlusion, radial spasm and pseudoaneurysm can be reduced by using the methods required by the procedure and applying compression for longer periods after the procedure. Additional measures to prevent pseudoaneurysm in patients on systemic anticoagulants may include the use of $4 \mathrm{Fr}$ sheath sizes that have been shown to be suitable for diagnostic angiography (8). However, as in our case, the physician's awareness of the possibility of pseudoaneurysm formation is very important for early diagnosis and treatment.

A pseudoaneurysm is the formation of a hematoma outside and around the parenchyma tissue. Unlike an aneurysm covered with the three layers of natural tissue (intima, media, and adventitia), a pseudoaneurysm is a false pouch surrounded by fibrous scar tissue. Compared to a simple hematoma, a pseudoaneurysm is often pulsatile. In our case, we observed pulsatile and palpable thrill in the radial artery region during the postoperative physical examination and this finding led to the definitive diagnosis that we made with Doppler USG. USG is a cheap, fast and dynamic modality in the imaging and diagnosis of pseudoaneurysms.

The treatment of radial pseudoaneurysm aims to repair the wall of the arterial lesion or interrupt the flow communication between the artery and parenchymal hematoma. Treatment usually depends on the etiology and location, patient's symptoms, presence of thrombus, distal circulation, and collateral formation. Radial pseudoaneurysm treatment includes compression, thrombin injection, or surgical treatment (9). Radial artery ligation has also been suggested in cases where collateral flow is thought to be sufficient (10). Another technique, as used in our case, is USG-assisted compression at 5-10 minute intervals until occlusion is achieved (11). Our case was characterized by complete regression with USG-assisted compression.

Pseudoaneurysm symptoms usually arise from hematoma-induced mass effect, ischemia, or nerve compres- 
sion. In most of the previously reported cases, the diagnosis was delayed because patients were examined after the development of symptoms, but in our case early diagnosis was achieved by the radial Doppler USG that we performed 24 hours after transradial CAG. USG-assisted compression, a nonoperative way of managing uncomplicated pseudoaneurysms of the radial artery, is a safe and useful treatment strategy (11). Another technique is thrombin injection into the pseudoaneurysm area, although direct thrombin injections into the pseudoaneurysm sac also have the risk of thromboembolism and necrosis in the distal artery bed (12). In addition, anaphylaxis is another complication reported after thrombin injections (13), and Zegri et al. reported asymptomatic radial artery occlusion after thrombin injection into the radial pseudoaneurysm sac (14). Surgical treatment is required in cases where conservative treatment fails (14).

In conclusion, in our case the rare complication of pseudoaneurysm after transradial CAG was diagnosed by physical examination and Doppler USG. It was then treated with intermittent USG-assisted compression therapy. After the treatment, the pseudoaneurysm disappeared, the radial artery flow was good, and the patient had no problem using her right arm during her daily activities. Given the increasing frequency of radial approaches, our experience indicates the need for a general awareness of post-transradial CAG complications, developing appropriate management strategies, and the importance of USG-assisted compression as a nonsurgical option in the treatment.

\section{Conflict-of-Interest and Financial Disclosure}

The authors declare that they have no conflict of interest to disclose. The authors also declare that they did not receive any financial support for the study.

\section{REFERENCES}

1. Jolly SS, Yusuf S, Cairns J, Niemelä K, Xavier D, Widimsky P, et al. Radial versus femoral access for coronary angiography and intervention in patients with acute coronary syndromes (RIVAL): a randomised, parallel group, multicentre trial. Lancet. 2011;377(9775):1409-20.

2. Bernat I, Horak D, Stasek J, Mates M, Pesek J, Ostadal P, et al. ST elevation myocardial infarction treated by radial or femoral approach in a multicenter randomized clinical trial: the STEMI-RADIAL trial. J Am Coll Cardiol. 2014;63(10):964-72.
3. Rao SV, Cohen MG, Kandzari DE, Bertrand OF, Gilchrist IC. The transradial approach to percutaneous coronary intervention: historical perspective, current concepts, and future directions. J Am Coll Cardiol. 2010;55(20):2187-95.

4. Kanei Y, Kwan T, Nakra NC, Liou M, Huang Y, Vales LL, et al. Transradial cardiac catheterization: a review of access site complications. Catheter Cardiovasc Interv. 2011;78(6):8406.

5. Walton NP, Choudhary F. Idiopathic radial artery aneurysm in the anatomical snuff box. Acta Orthop Belg. 2002;68(3):292-4.

6. Avtandil MB, Samir BP, Dmitriy SK. New technique for treatment of postcatheterization radial artery pseudoaneurysm. Catheter Cardiovasc Interv. 2017;89(3):393-8.

7. Collins N, Wainstein R, Ward M, Bhagwandeen R, Dzavik V. Pseudoaneurysm after transradial cardiac catheterization: case series and review of the literature. Catheter Cardiovasc Interv. 2012;80(2):283-7.

8. Lefevre T, Morice MC, Bonan R, Dumas P, Louvard Y, Karrillon $\mathrm{G}$, et al. Coronary angiography using 4 or 6 French diagnostic catheters: a prospective, randomized study. J Invasive Cardiol. 2001;13(10):674-7.

9. D’Achille A, Sebben RA, Davies RP. Percutaneous ultrasound-guided thrombin injection for coagulation of post-traumatic pseudoaneurysms. Australas Radiol. 2001;45(2):218-21.

10. Ganchi PA, Wilhelmi BJ, Fujita K, Lee WP. Ruptured pseudoaneurysm complicating an infected radial artery catheter: case report and review of the literature. Ann Plast Surg. 2001;46(6):647-50.

11. Toursarkissian B, Allen BT, Petrinec D, Thompson RW, Rubin BG, Reilly JM, et al. Spontaneous closure of selected iatrogenic pseudoaneurysms and arteriovenous fistulae. J Vasc Surg. 1997;25(5):803-9.

12. Khoury M, Rebecca A, Greene K, Rama K, Colaiuta E, Fly$\mathrm{nn} \mathrm{L}$, et al. Duplex scanning-guided thrombin injection for the treatment of iatrogenic pseudoaneurysms. J Vasc Surg. 2002;35(3):517-21.

13. Pope M, Johnston KW. Anaphylaxis after thrombin injection of a femoral pseudoaneurysm: recommendations for prevention. J Vasc Surg. 2000;32(1):190-1.

14. Zegrí I, García-Touchard A, Cuenca S, Oteo JF, FernándezDíaz JA, Goicolea J. Radial artery pseudoaneurysm following cardiac catheterization: clinical features and nonsurgical treatment results. Rev Esp Cardiol. 2015;68(4):349-51. 